\title{
The Book of Numbers at Qumran: Texts and Context
}

Dana M. Pike

Brigham Young University, dana_pike@byu.edu

Follow this and additional works at: https://scholarsarchive.byu.edu/facpub

Part of the Biblical Studies Commons

\section{Original Publication Citation}

Pike, Dana M. "The Book of Numbers at Qumran: Texts and Context," Conference on the texts from the Judean Desert (Leiden : E.J. Brill, 1996)

\section{BYU ScholarsArchive Citation}

Pike, Dana M., "The Book of Numbers at Qumran: Texts and Context" (1996). Faculty Publications. 4374. https://scholarsarchive.byu.edu/facpub/4374

This Book Chapter is brought to you for free and open access by BYU ScholarsArchive. It has been accepted for inclusion in Faculty Publications by an authorized administrator of BYU ScholarsArchive. For more information, please contact ellen_amatangelo@byu.edu. 


\section{The Book of Numbers at Qumran:} Texts and Context

\section{DANA M. PIKE}

\author{
Brigham Young University
}

In this paper I examine the significance of the book of Numbers for the covenant community at Qumran. By way of background, I will relate the reason I chose this topic.

My assignment as an editor of fragments for $D J D$ is to prepare about sixty plates of miscellaneous and mainly unidentified fragments from Cave 4 at Qumran for publication. While some of these fragments have been identified and have been or will be published by others, I have well over 1,000 fragments with which to work. Most are quite small. Andrew Skinner, a colleague of mine at Brigham Young University, has recently joined me in this task.

I appreciate the opportunity extended to me by FARMS to participate in this conference and the support of the Department of Ancient Scripture at Brigham Young University. I thank Professor Emanuel Tov for the opportunity to prepare some of the material from Qumran Cave 4, previously a portion of John Strugnell's allotment, for publication in DJD 32 .

Please note that all passages quoted from the Bible follow the NRSV, and that English translations of Qumran texts follow Geza Vermes, The Dead Sea Scrolls in English, 4th ed. (New York: Penguin, 1995), unless otherwise indicated. My alterings of Vermes's use of "Thee, Thine," etc., are enclosed in stylized brackets \{ \} so as to be distinguishable from his textual restorations in square brackets [ ].
While reviewing these plates I noticed a fragment assemblage on PAM 43.679 that contained the first few verses of Numbers 4 , but I could find no previous mention of a fragment of Numbers on this plate. It did not take long to discover that this fragment was a portion of $4 Q L e v-N u m^{a}$ that has recently been published by Professor Eugene Ulrich in DJD 12, in which it is designated as fragment 35 . $^{1}$ Neither Ulrich nor anyone else seems to have been aware that this fragment, along with an additional small piece that was not published in DJD 12, was on PAM 43.679, a photo that was taken later than the plates cited for this fragment in $D J D$ 12. This small fragment contains the lower 90 percent of the letters of two words, the tops of which are preserved on the fragment to which it joins. ${ }^{2}$ Ulrich was happy to learn that he had restored the text correctly at this point! These fragments are no longer physically located on PAM 43.679, but fragment 35 , along with this additional small piece, are found on PAM 43.035 (Mus Inv \#419). ${ }^{3}$ I mention this experience to update the information on $4 Q L e v-N u m^{a}$ in DJD 12 and to highlight the excitement and the frustration involved in trying to track fragments through multiple arrangements on many plates.

Even though I have no new fragment of Numbers on which to report, I was motivated to determine, at least in a preliminary fashion, the significance of Numbers for the community at Qumran. To accomplish this purpose I will first review the number and nature of the textual witnesses of Numbers found at Qumran. This analysis will be followed in the second portion of the paper by a survey of the passages from Numbers as they are $\rightarrow$

1 Eugene Ulrich, ed., "4QLev-Numa," in Qumran Cave 4, VII: Genesis to Numbers, ed. Eugene Ulrich et al., DJD 12 (Oxford: Clarendon, 1994), 165, pl. 27.

2 The fragment contains the major portion of the letters לה וער סק

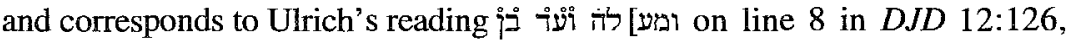
"Frgs. 32 col. ii, 34 col. i-43" (Numbers 3:51-4:12).

3 I thank Andrew Skinner for confirming the location of these fragments in the Rockefeller Museum. 
used in the principal sectarian documents of the community at Qumran.

\section{The Text of Numbers at Qumran}

It is common practice to judge the significance of a biblical book at Qumran by the number of copies of that book that have been discovered there. While this approach has inherent drawbacks, such as the random nature of preservation, it is clear that there is merit, at least in relative terms, in relating the number of preserved copies of a book to the community's perception of the value of that book. On this basis it has been observed that the portions of the thirty-six copies of Psalms, the portions of the twenty-nine copies of Deuteronomy, and the portions of the twenty-one copies of Isaiah (one nearly complete) that have been discovered in the caves around Qumran indicate the popularity and significance of these books in the Qumran community. Following these books in number of attested copies are three of the books of the Torah-portions of seventeen copies of Exodus, portions of fifteen copies of Genesis, and portions of thirteen copies of Leviticus are preserved. Although portions of eight copies of Numbers are cited as being preserved, I prefer to count only seven, for reasons discussed below. ${ }^{5}$ This smaller

4 These figures are given by James C. VanderKam, The Dead Sea Scrolls Today (Grand Rapids, Mich.: Eerdmans, 1994), 30-31. The most convenient way to compute the number of copies of biblical books discovered at Qumran is to use Stephen Reed, comp., with Marilyn J. Lundberg, ed., The Dead Sea Scrolls Catalogue (Atlanta: Scholars Press, 1994). However, the way some fragments are counted and the confidence given to some identifications will obviously result in different figures. See, for example, the generally higher calculations cited by Lawrence H. Schiffman, Reclaiming the Dead Sea Scrolls (Philadelphia: Jewish Publication Society, 1994), 163. Neither VanderKam nor Schiffman cite a source for their figures. See also Emanuel Tov, Textual Criticism of the Hebrew Bible (Minneapolis, Minn.: Fortress, 1992), 104-5.

5 It is not clear to me how Schiffman, Reclaiming the Dead Sea Scrolls, 163, arrived at twelve "Qumran manuscripts" of Numbers. quantity in comparison with the other books of the Torah is not too surprising. Genesis and Exodus contain many foundational episodes of significance to Israelites. The emphasis placed on the Law by Jews of the Second Temple period, as found in Exodus and especially in Leviticus and Deuteronomy, would account, at least in part, for the relative frequency of attestation of these books at Qumran. The relationship of the contents of Numbers to the interests of the community will be discussed in the next section of this paper. I here emphasize that while more copies of Numbers are preserved at Qumran than copies of the so-called historical books and some of the prophetic books, Numbers is by far the least well attested, and thus seemingly the least significant, of any of the books of the Torah for the Qumran community. ${ }^{6}$

With this perspective in mind, I will now review the textual nature of the copies of Numbers that have been discovered and then note how this data correlates with the general picture of biblical texts preserved at Qumran. ${ }^{7}$ The following texts of Numbers have been found in Caves 1 and 2.

$6 \quad$ Note that fragments of Numbers have been discovered elsewhere in the Judean desert: there is evidence of two copies from Nahal Hever and one from Wadi Murabba ${ }^{c} \bar{a}$; Reed and Lundberg, The Dead Sea Scrolls Catalogue, 227, 263. However, these manuscripts are not included in this survey of Numbers at Qumran.

For a recent review of the evidence of the copies of Deuteronomy from the Judean desert, similar to my approach in the first portion of this paper, see Florentino García Martínez, "Les manuscrits du désert de juda et le Deutéronome," in Studies in Deuteronomy, ed. Florentino García Martínez et al. (New York: Brill, 1994), 63-82. I thank Professor García Martínez for sharing a copy of this article with me. 


\section{$1 Q 3$, referred to variously as $1 Q$ paleoLeviticus, 1QpaleoLeviticus $\left(+N\right.$ umbers) and 1 QpaleoNumbers $(?)^{8}$}

Originally published by editor D. Barthélemy with the view that these several, small pieces of a paleo-Numbers text might have been on the same scroll as a paleo-Leviticus text, ${ }^{9}$ these fragments are now thought to have comprised a separate manuscript. ${ }^{10}$ Only two of the fragments, numbers 8 and 9 , preserve text of any consequence, and fragment 9 has full orthography, against the MT, in one of the two words preserved. Given the orthography and the paleo-Hebrew script, one might be tempted to associate this text with the pre-Samaritan witnesses, but the minimal evidence does not make it possible to determine which textual witness these fragments of Numbers represent. This is the only copy of Numbers preserved in paleo-Hebrew at Qumran. $^{\text {I1 }}$

\section{$2 Q 6$, or $2 Q N u m b e r s^{12}$}

Two small fragments exist that appear to represent the tradition of the MT, as noted by editor M. Baillet, ${ }^{13}$ but they are not much to work with.

8 Dominique Barthélemy, "Lévitique et autres fragments en écriture 'phénicienne,' " in Qumran Cave I, DJD 1, ed. Dominique Barthélemy and Josef T. Milik (Oxford: Clarendon, 1955), 53, pl. 9; preserves portions of Numbers 1 and 36 .

9 See $D J D$ 1:51-53. These fragments of Numbers are listed under 1Q3, "paleoLev," in Reed and Lundberg, The Dead Sea Scrolls Catalogue, 15 .

10 See Mark D. McLean, "The Use and Development of PalaeoHebrew in the Hellenistic and Roman Periods" (Ph.D. diss., Harvard University, 1982), 42, 60; and Tov, Textual Criticism, 105 n. 79.

It is interesting to note in passing that all five books of the Torah are represented at Qumran by at least one paleo-Hebrew text.

Maurice Baillet, "Nombres (premier exemplaire)," in Les 'petites grottes' de Qumran, DJD 3, ed. Maurice Baillet, Josef T. Milik, and Roland De Vaux (Oxford: Clarendon, 1962), 57-58, pl. 12; preserves portions of Numbers 3:38-41 and 3:51-4:3.

\section{$2 Q 7$, or $2 Q N u m b e r s^{b 14}$}

One small fragment with examples of full orthography and two attestations of the plural pronominal suffix מה -, against the MT, suggested to Baillet a possible association with the tradition of the Samaritan Pentateuch. ${ }^{15}$ Emanuel Tov tentatively classified $2 Q_{N u m^{b}}$ as a text that exhibits evidence of the Qumran scribal practice, but found "insufficient evidence" to be certain. ${ }^{16}$

\section{$2 Q 8$, or $2 Q N u m b e r s^{17}$}

One small fragment has three and a half words preserved on two lines. These words occur only once in the Bible in the combination found on the fragment, making the identification fairly certain; however, not much evidence exists for determining which textual witness is represented.

\section{$2 Q 9$, or $2 Q N u m b e r s^{d 18}$}

The few partial words preserved on this small fragment do not allow any conclusions. Note, however, that one word is written plene, against the MT. Baillet remarked that "I'identification est conjecturale," suggesting that this may be a fragment of $2 Q_{N u m^{b}}$, and others have reiterated his reservations. ${ }^{19}$ I mention this fragment here, but do not include it for purposes of computing the number of copies of Numbers found at Qumran.

13 DJD 3:57

14 DJD 3:58-59, pl. 12; preserves portions of Numbers 33:47-53.

15 DJD 3:58.

16 Emanuel Tov, "The Orthography and Language of the Hebrew Scrolls Found at Qumran and the Origin of These Scrolls," Textus 13 (1986): 54; see also Tov, "Hebrew Biblical Manuscripts from the Judaean Desert: Their Contribution to Textual Criticism," JJS 39 (1988): 15 n. 39.

17 DJD 3:59, pl. 12; preserves a portion of Numbers 7:88.

18 DJD 3:59-60, pl. 12; perhaps preserves a portion of Numbers 18:8-9.

19 Baillet, "Nombres (quatrième exemplaire?)," in DJD 3:59. See also, for example, Reed and Lundberg, The Dead Sea Scrolls Catalogue, 34. 
Obviously, all the fragments of Numbers from Caves 1 and 2 are quite small. They do not generally constitute sufficient evidence for determining the nature of their textual witness, nor is it possible to assert with confidence that they all represent individual copies of Numbers, as opposed to quotations or excerpts from Numbers in some other text. A number of texts from Cave 4 also exist.

\section{$4 Q 23$, or $4 Q L e v i t i c u s-N u m b e r s a^{20}$}

Editor Eugene Ulrich notes that "the manuscript is carefully and clearly inscribed in an early Hasmonaean formal script, dating from approximately the middle or latter half of the second century BCE." He further notes that "the orthography is generally similar to that of $\mathrm{nt}$ and $\mu, "$ although some inconsistency is found in each of the witnesses. ${ }^{21}$ The text, especially those portions preserving Numbers, basically reflects that of the MT and can thus be described as proto-Masoretic.

\section{$4 Q 27$, or $4 Q N u m b e r s^{22}$}

According to Nathan Jastram, who edited this text, "the orthography of $4 Q^{2}$ um $^{b}$ is very full." Jastram cites Cross's analysis of the script of $4 Q N u m^{b}$ as "Early Herodian semiformal"; this manuscript thus dates from between 30 B.C.E. and C.E. 20 , although Jastram and Cross favor "the earlier portion of that range." Concerning the character of the text, Jastram states that "the array of readings in 4 QNumb sets up a remarkable pattern of correlation with the other textual witnesses of the book of Numbers," including the LXX and especially the SP. Furthermore, $4 Q N{ }^{b}{ }^{b}$ "has a significant number of unique readings."23

20 DJD 12:153-76, pl. 23-30; preserves portions of Numbers 1-4; $8-13 ; 22 ; 26 ; 30-35$.

21 Ulrich, "4QLev-Numa," in $D J D$ 12:154.

22 DJD 12:205-67, pl. 38-49; preserves portions of most of the chapters of Numbers 11-36.

23 Nathan Jastram, "4QNumb," in $D J D$ 12:211-15.
$4 Q N u m^{b}$ is classified as "pre-Samaritan," and Tov has described this text as an example of the so-called Qumran scribal practice. $^{24}$

\section{$4 Q 121$, or $4 Q L X X N u m b e r s^{25}$}

Noting a "few possible minor orthographic or phonological differences between 4QLXXNum and [the LXX]," editor Ulrich describes this text as a "superior witness to the Old Greek translation." He suggests that the paleography dates this text "from around the late first century B.C.E. or the early first century C.E." $" 26$

The remains of the three copies of Numbers found in Cave 4-4QLev-Num ${ }^{a}, 4 Q N u m^{b}$, and $4 Q L X X N u m$ - have close affinities with what have become known as the MT, the SP, and the $\mathrm{LXX}$, respectively, although $4 Q N u m^{b}$ does go its own way occasionally. Again, this latter text has been categorized by Tov as representing the Qumran scribal practice. Since the remains of copies of Numbers from Caves 1 and 2 are scanty, the most that can be said with any degree of confidence is that one text, $2 Q 6$, or $2 Q N u m^{a}$, is most likely proto-Masoretic, while another, $2 Q 7$, or $2 Q_{N u m}^{b}$, may be pre-Samaritan or represent the Qumran scribal practice.

This survey reveals that of the seven likely copies of the text of Numbers preserved in the Qumran caves (discounting 2Q9), only five of them-2QNum ${ }^{a}$ and $2 Q N u m^{b}, 4 Q L e v-N u m^{a}$, $4 Q N u m^{b}$, and $4 Q L X X N u m$ - can be employed with relative confidence as witnesses of the text of this biblical book. Of

24 Tov, Textual Criticism, 99, 109, 115; see also Emanuel Tov, "Groups of Biblical Texts Found at Qumran," in Time to Prepare the Way in the Wilderness, ed. Devorah Dimant and Lawrence H. Schiffman (Leiden: Brill, 1995), 97.

25 Eugene Ulrich, "4QLXXNumbers," in Qumran Cave 4, IV: Palaeo-Hebrew and Greek Biblical Manuscripts, DJD 9, ed. Patrick W. Skehan, Eugene Ulrich, and Judith E. Sanderson (Oxford: Clarendon, 1992), 187-94, pl. 42-43; preserves portions of Numbers 3-4.

26 DJD 9:188-89. 
these five, two, or 40 percent, are proto-Masoretic texts; one, or 20 percent, is LXX; and two, or 40 percent, may be preSamaritan or exhibit the Qumran scribal practice. Note that this breakdown is not consistent with the approximate figures computed by Tov concerning the types of biblical texts at Qumran:

$\begin{array}{lc}\text { Proto-Masoretic Texts } & 60 \% \\ \text { Texts in the Qumran Style } & 20 \% \\ \text { Nonaligned Texts } & 10 \% \\ \text { Pre-Samaritan Texts } & 5 \% \\ \text { Texts associated with the LXX } & 5 \%{ }^{27}\end{array}$

Thus the evidence that has been preserved suggests greater diversity in the texts of Numbers that were included in the community's library, most of which appear to have been brought to Qumran, than is found in the overall picture suggested by Tov's calculations. Unfortunately, this observation is of little value in our efforts to understand the community's view of the text of Numbers, since this breakdown itself does not tell us in what regard the Qumran people held these various textual witnesses of Numbers nor to what use they put them. Furthermore, our sample of texts is so relatively small that it is not possible to tell if it is statistically valid. This situation does serve to remind us, however, that while the proto-Masoretic text was on average the more frequently attested text in the community's archives, this may not have been the case for every book that eventually found its place in the biblical canon, including Numbers.

27 See Tov, Textual Criticism, 115-17. This must be the source for the figures cited by Schiffman, Reclaiming the Dead Sea Scrolls, 171-72. Tov's earlier, preliminary figures, apparently employed by VanderKam in The Dead Sea Scrolls Today, 134, for example, were published in "Groups of Biblical Texts Found at Qumran," 101. Note that the work of all the contributors to Dimant and Schiffman, eds., Time to Prepare the Way in the Wilderness, including this article by Tov, was completed by 1990 , even though the publication date is 1995 .

\section{The Book of Numbers in Context at Qumran}

Besides quantifying evidence of preserved manuscripts, another means of evaluating the significance of Numbers or any book at Qumran is to evaluate the impact of the book on the community's own literature by evaluating the use made of the book's contents (themes or significant passages) in the sectarian documents. I am not talking here about portions of Numbers that appear in works such as $4 Q R$ [eworked]P[entateuch] or Jubilees, but in the principal works of the community. Although some studies have focused on the biblical materials in a particular sectarian document, ${ }^{28}$ the approach taken here is basically different, i.e., to examine evidences of the influence of one biblical book in the context of the sectarian documents.

Such an approach necessitates defining the sectarian corpus of the community, and on this scholars exhibit relative unanimity. Examples of attempts to define, to one degree or another, the principal corpus of the Qumran group include those of (1) Dimant, who distinguishes between texts exhibiting what she terms "community terminology" and those that do not; ${ }^{29}$ (2) Talmon, who refers to "foundation documents"; 30 and (3) Tov, who categorizes texts according to evidence of the Qumran

28 See, for example, P. Wernberg-Møller, "The Contribution of the Hodayot to Biblical Textual Criticism," Textus 4 (1964): 133-75; and Jean Carmignac, "Les citations de l'Ancien Testament dans 'La Guerre des Fils de Lumière contre les Fils de Ténèbres,' " $R B 63$ (1956): 375-90. Other studies have overviewed the situation, citing many biblical passages as attested in many Qumran documents. See, for example, Andrew Chester, "Citing the Old Testament," in It Is Written: Scripture Citing Scripture, ed. D. A. Carson and H. G. M. Williamson (Cambridge: Cambridge University Press, 1988), 141-50.

29 Devorah Dimant, "The Qumran Manuscripts: Contents and Significance," in Time to Prepare the Way in the Wilderness, 31-33.

30 Shemaryahu Talmon, "The Community of the Renewed Covenant: Between Judaism and Christianity," in The Community of the Renewed Covenant: The Notre Dame Symposium on the Dead Sea Scrolls, ed. Eugene Ulrich and James VanderKam (Notre Dame: University of Notre Dame Press, 1994), 11. 
scribal practice or the lack thereof. ${ }^{31}$ Their views on what texts constitute the principal corpus of the community's own works are summarized in the following chart:

$\begin{array}{lll}\text { Dimant } & \text { Talmon } & \text { Tov } \\ \text { IQS: } \text { Rule of the } & \text { IQS } & \text { IQS } \\ \text { Community } & & \end{array}$

1QSa: Rule of the

$\operatorname{IQSa}$

Congregation

lQSb: Rule of the Blessings

IQM: War Scroll

$I Q M \quad I Q M$

IQH: Hodayot

$I Q H$ ("to some $1 Q H$

CD: Damascus

extent

$C D$

Document

Songs of the Sabbath Sacrifice ("partly")

pesherim (including bib- $1 Q p H a b$

lical pesherim, Melchi-

zedeq, Florilegium, etc.)

Mysteries

Rule of the Farmer

4QMMT: Miqșat Ma'aśe

Ha-Torah

Saniential texts

Prayers for Festivals

Temple Scroll ${ }^{32} \quad$ Temple Scroll

31 Tov, "The Orthography and Language of the Hebrew Scrolls," and Tov, "Hebrew Biblical Manuscripts from the Judaean Desert," 10-16.

32 Interestingly, Dimant lists the Temple Scroll as a text that does not exhibit "community terminology," while Talmon, "The Community of the Renewed Covenant," 11, specifically states that it is a "foundation document" of the covenant community. Dimant is not alone in postulating that the Temple Scroll is not a document that originated with the community; see also, for example, Lawrence H. Schiffman, Sectarian Law in the Dead Sea Scrolls (Chico, Cal.: Scholars Press, 1983), 14. However, those
Since disagreement exists among scholars concerning which documents qualify as "foundation documents" or as texts containing "community terminology," I have elected to work with those documents found on at least two of the above three lists, reviewing them for quotations or other evidence of influence from Numbers. The following discussion deals with the relevant connections in a topical fashion. All these connections have been observed before, but to my knowledge they have never been collected for the purpose of the evaluation undertaken here.

\section{Ages for various types of service}

There are several correlations between the age requirements prescribed in the Bible for levitical service and the age requirements for the activity of males in the Qumran community. For example, Numbers 8:24 declares that "from twenty-five years old and upward [the Levites] shall begin to do duty in the service of the tent of the meeting." This may be compared with the Rule of the Congregation, IQSa, I 12-13, which declares that "at the age of twenty-five years he may take his place among the foundations (i.e., the officials) of the holy congregation to work in the service of the congregation." Since admittance into the covenant community could take place at a minimum of twenty years of age (1QSa I 9-11; CD XV 5-6), it appears that twentyfive years is the minimum age restriction regarding "service" involving officiating. ${ }^{33}$ Thus, according to $C D \times 4-10$, twentyfive was the minimum age for a man to be a judge in the congregation. This minimum age benchmark is associated with a dif-

who share Talmon's opinion include Vermes, The Dead Sea Scrolls in English, 152, and Yigael Yadin, ed., The Temple Scroll, 3 vols. (Jerusalem: Israel Exploration Society et al., 1983), 1:390-99. Although a valid case can be made for suggesting that the Temple Scroll did not originate at Qumran, I have decided to treat it as one of the community's principal documents in this discussion.

${ }^{33}$ For a convenient discussion of this see Lawrence H. Schiffman, The Eschatological Community of the Dead Sea Scrolls: A Study of the Rule of the Congregation (Atlanta: Scholars Press, 1989), 20. 
ferent function in the War Scroll, $1 Q M$, VII 2-3, which records that "the despoilers of the slain, the plunderers of booty, the cleansers of the land, the keepers of the baggage, and those who furnish the provisions shall be from twenty-five to thirty years old. ${ }^{34}$ While no specific mention is made in these Qumran texts of the passage in Numbers 8 about the initial age for levitical service, the fact that the age for significant types of service at Qumran matches the minimum age for levitical service is certainly suggestive of conscious patterning or reliance. This reliance probably has more to do with actual practice in Jewish society, based on the tradition of Numbers 8 , than on mere literary influence.

Similarly, a correlation seems to exist between other age requirements in principal sectarian documents from Qumran and Numbers 4. In this biblical passage YHWH instructed Moses and Aaron to take a census of the Levites who were thirty to fifty years of age, by their clans. After they had fulfilled this command, we read: "all those who were enrolled of the Levites, whom Moses and Aaron and the leaders of Israel enrolled, by their clans and their ancestral houses, from thirty years old up to fifty years old, everyone who qualified to do the work of service and the work of bearing burdens relating to the tent of meeting, their enrollment was eight thousand five hundred eighty" (Numbers 4:46-48). These verses strongly suggest that active levitical service began at a minimum age of thirty years, a seeming contradiction to the prescription just mentioned in Numbers 8, which defines twenty-five years of age as the minimum. Among the various attempts to reconcile this apparent discrepancy is the rabbinic suggestion that a twenty-five year old Levite was in training for a period of five years, becoming an

34 Again, discussed by Schiffman, The Eschatological Community, 22, who relies on Yigael Yadin, The Scroll of the War of the Sons of Light against the Sons of Darkness, trans. by B. Rabin and Chaim Rabin (Oxford: Oxford University Press, 1962), 76-79. active participant at the age of thirty. ${ }^{35}$ Several passages in the community's principal documents mention a minimum age of thirty for certain activities. The Damascus Document records that "the Priest who enrolls the Congregation shall be from thirty to sixty years old" (XIV 6-7). The next few lines of the Damascus Document stipulate that "the Guardian of all the camps shall be from thirty years to fifty years old" (XIV 8-9). ${ }^{36}$ Thirty is also the minimum age requirement for official responsibilities in the eschatological Qumran community, as outlined in $1 Q S a$ I 14-18: "at the age of thirty years he may approach to participate in lawsuits and judgments, and may take his place among the chiefs of the Thousands of Israel, the chiefs of the Hundreds, Fifties, and Tens, the Judges and the officers of their tribes, in all their families, [under the authority] of the sons of [Aar]on the Priests." Likewise, the War Scroll VI 12-13 cites thirty as the minimum age for cavalrymen in the great eschatological battle: "their riders shall be gallant fighting men and skilled horsemen, and their age shall be from thirty to forty-five years." ${ }^{\text {"3 }}$ The explanation that young Levites spent five years in preparatory service, from age twenty-five to thirty, helps clarify the requirements for military service in the Qumran sectarian documents: while service of a training and background nature began at twenty-five, active duty did not begin until thirty.

It should be mentioned here that not only age requirements, but also matters of general organization in the community seem to be modeled after patterns found in Numbers $1-10 .{ }^{38}$ Regard-

35 Discussed by Schiffman, The Eschatological Community, 22, who cites, in n. 64, Sifre Be-Midbar 62, Numbers Rabba 4:12, and so on.

36 Note that this age span is incorrectly rendered as "between thirty and sixty [sic] years of age," in Florentino García Martínez, The Dead Sea Scrolls Translated: The Qumran Texts in English, trans. Wilfred G. E. Watson (Leiden: Brill, 1994), 44.

37 Again, this is discussed by Schiffman, The Eschatological Community, 21-22, with references to Yadin and others.

38 See, for example, the comments of Yadin, The Scroll of the War, 38-64, and Philip R. Davies, IQM, the War Scroll from Qumran: Its Structure and History (Rome: Biblical Institute Press, 1977), 28-35. 
ing this, Schiffman has observed that "the system of authority and communal structure envisaged for the end of days was a reflection of that practiced by the sect in their attempt to live the eschatological life in this world. . . . Here again we see the nexus of the desert heritage with the eschatological future. The very same communal and military organization which cemented the desert community of Israel was put into practice to the greatest extent possible by the sect." ${ }^{\prime 39}$ Note again that no passage from Numbers is directly quoted or referred to, but the awareness of and reliance on these passages from Numbers by the community at Qumran cannot be missed.

\section{The Priestly Blessing}

Given the significance of the Aaronic priestly blessing (Numbers 6:22-28) in the Bible and in Second Temple period Judaism, and the emphasis on a righteous priestly leader at Qumran, it would be a surprise not to find any attestation of this blessing in the principal sectarian documents of the Qumran community.

The LORD spoke to Moses, saying:

Speak to Aaron and his sons, saying,

Thus you shall bless the Israelites: You shall say to them,

The LORD bless you and keep you;

יברכך יהוה וישמרך

the LORD make his face to shine upon you, and be gracious to you;

$$
\text { יאר יהוה פניו אליך ויחנך }
$$

the LORD lift up his countenance upon you, and give you peace.

$$
\text { יעוא יהוה פניו אליך וישם לך שילום }
$$

39 Schiffman, The Eschatological Community, 23.
So they shall put my name on the Israelites, and I will bless them.

(Numbers 6:22-27)

Although the passage is not quoted intact in any of the community's surviving documents, it has long been recognized that an expanded form of the priestly blessing does occur in the Rule of the Community, IQS, and that several phrases of the blessing occur in the Rule of the Blessings, 1QSb (1Q28b). Consider these lines from $1 Q S$ II $2-4$, in which the additions to the biblical text are italicized:

May He bless you with every good and keep you from every evil;

May He enlighten your heart with immortal wisdom and favor you with eternal knowledge;

May He lift up his merciful countenance upon you for eternal peace. ${ }^{40}$

Bilhah Nitzan has commented on "the addition of a concise homily connected to each verb of the priestly blessing recited in the biblical form., ${ }^{41}$

While phrases and words of the priestly blessing are evident in $l Q S b$, they are used in a more random or varied way, in contrast to $1 Q S$. Note that key words and phrases from the priestly blessing are attested in I 3 (יברכבה ז[דני[) and 5

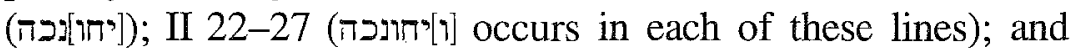

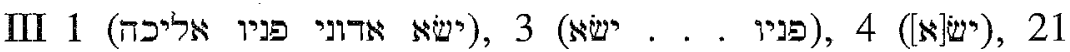
(יברככה אדני) (יוני), This led Schiffman to conclude that "most of the text may be regarded as an expansion upon the

40 Translation by Bilhah Nitzan, Qumran Prayer and Religious Poetry (Leiden: Brill, 1994), 148

41 Ibid. See George J. Brooke's discussion of this passage in Exegesis at Qumran (Sheffield: JSOT, 1985), 295-301, in which he comments on the "expansions of the benediction of Num 6:24-26 [as] a clear example of the exegetical technique of 'asmaktâ, the use of biblical citations and allusions to support a biblical quotation" (pp. 298-99). 
priestly blessing," poetic use of selected verbs from the blessing." ${ }^{43}$ It seems clear that these passages in $1 Q S b$ exhibit conscious literary dependence on the priestly blessing in Numbers 6 .

\section{Balaam's Prophecy}

Of the four passages from Numbers that are quoted and interpreted in the Damascus Covenant or Document $(C D)$, Numbers $24: 17$ is the most significant. This is the passage in which Balaam prophesies about a star and scepter:

I see him, but not now;

I behold him, but not near-

a star shall come out of Jacob,

and a scepter shall rise out of Israel;

it shall crush the borderlands of Moab,

and the territory of all the Shethites.

(Numbers 24:17)

A portion of Balaam's statement is quoted and interpreted in $C D$ VII 19-21; however, it is preceded by quotations from, and interpretations of, phrases from Amos 9:11 and Amos 5:27:

When the two houses of Israel were divided, Ephraim departed from Judah. And all the apostates were given up to the sword, but those who held fast escaped to the land of the north; as God said: I will exile the tabernacle of your king and the bases of your statues from my tent to Damascus (Amos v, 26-7).

The Books of the Law are the tabernacle of the king; as God said, I will raise up the tabernacle of David which is fallen (Amos ix, 11). The king is the congrega-

42 Schiffman, The Eschatological Community, 74, in which he also outlines the key words and phrases as listed here.

43 Nitzan, Qumran Prayer, 148. tion; and the bases of the statues are the Books of the Prophets whose sayings Israel despised. The star is the Interpreter of the Law who shall come to Damascus; as it is written, A star shall come forth out of Jacob and a sceptre shall rise out of Israel (Num. xxiv, 17). The sceptre is the Prince of the whole congregation, and when he comes he shall smite all the children of Seth (Num. xxiv, 17). (CD VII 12-21)

The star is equated with the "Interpreter of the Law," דורש תורה, who is best understood as the great priestly figure of the future, referred to elsewhere as "Messiah," משיח, and "Chief Priest," (כ) "כhe scepter with the "prince of the congregation," ניאיא (כל) העדה, correlates with other passages that refer to this "prince" as the great messianic military leader. ${ }^{45}$ This passage in Numbers 24:17 was thus seen by those in the community at Qumran as referring to the two eschatological messiahs, the priestly ("star") and the davidic ("scepter"). While it is true that a messianic interpretation of this passage is not unique to Qumran, the way it is woven with commentary into the Damascus Document indicates that the Qumran community had made it their own. ${ }^{46}$

44 See, conveniently, the recent summary of messianic related titles by James VanderKam, "Messianism in the Scrolls," in Community of the Renewed Covenant, 220-34.

45 See ibid., 212-19, especially 218-19, in which VanderKam discusses passages from $1 Q S b, 1 Q M, 4 Q p I s a^{a}$, and $4 Q 285$, concluding that the "Prince of the [whole] congregation" is one of the "three principal messianic titles for the davidic messiah [the others being 'Messiah' and 'Branch of David'], and as noted earlier, the three are equated with one another" (ibid., 219). See also John J. Collins, The Scepter and the Star: The Messiahs of the Dead Sea Scrolls and Other Ancient Literature (New York: Doubleday, 1995), 63-64; pages 80-82 contain Collins's summary discussion and evaluation of the "Amos-Numbers midrash."

46 For a convenient survey of non-Qumran documents in which Numbers $24: 17$ is viewed messianically (Philo, Aqiba, and so on), see Collins, The Scepter and the Star, 63-64. 
It is also important to note that Numbers $24: 17$ is quoted in two other texts attributed to the Qumran community, IQM and 4QTest (4Q175). In neither case does explicit interpretation accompany the quotation, but the context in both instances is eschatological. The passage in $1 Q M$ contains praises of God's power and means of deliverance:

Truly the battle is \{Yours \} and the power from \{You\}! It is not ours. Our strength and the power of our hands accomplish no mighty deeds except by \{Your\} power and by the might of \{Your\} great valour. This \{You have \} taught us from ancient times, saying, A star shall come out of Jacob, and a sceptre shall rise out of Israel. He shall smite the temples of Moab and destroy all the children of Sheth. He shall rule out of Jacob and shall cause the survivors of the city to perish. The enemy shall be his possession and Israel shall accomplish mighty deeds (Num. xxiv, 17-19). (IQM XI 5-7) ${ }^{47}$

Balaam's prophecy of a star and scepter, included in 4QTest, lines 9-13, is placed in the context of four other biblical passages, including Deuteronomy 18:18-19 ("I will raise up for them a prophet like you"), which immediately precedes the quotation of Numbers 24:15-17. The perception at Qumran of the messianic nature of such passages reminds us again that Numbers 24:17 was understood and employed as a significant messianic prophecy at Qumran. ${ }^{48}$

Also deserving of mention in this regard is the blessing on the "prince of the congregation," found in $1 Q S b \mathrm{~V} 27$, in which it is said of the prince that "God raised you up as a scepter/rod

47 Note Collins's disagreement with Fitzmyer that this context $(I Q M)$ precludes the fulfillment of this prophecy by a messianic figure; Collins, The Scepter and the Star, 65.

${ }^{48}$ See Brooke, Exegesis at Qumran, 311-19, for interesting comments on the relationship between the structure and content of $4 Q T e s t$.
(نבט)," again suggesting a link between the content of Numbers 24:17 and the future messiah of the Qumran community. ${ }^{49}$

\section{The "Song of the Well"}

Numbers 21 contains the story of the Israelites' trek around Edom as they headed north for the Arnon and Moab. The episode of Moses making the bronze serpent is related in Numbers 21:4-9, followed by an account of several of the places the Israelites stopped on their journey. Then we read,

From there they continued to Beer; that is the well of which the LORD said to Moses, "Gather the people together, and I will give them water." Then Israel sang this song:

"Spring up, O well!- Sing to it!-

the well that the leaders [שים] sank,

that the nobles of the people dug,

with the scepter, with the staff."

(Numbers 21:16-18)

The majority of this "song" is quoted in $C D$ VI 3-4. After hearing that Israel had strayed from their covenants with the Lord, we read that

God remembered the Covenant with the forefathers, and he raised from Aaron men of discernment and from Israel men of wisdom, and He caused them to hear. And they dug the Well: the well which the princes [ים' which the nobles of the people delved with the stave (Num. xxi, 18). The Well is the Law, and those who dug it were the converts of Israel who went out of the land of Judah to sojourn in the land of Damascus. God called them all princes because they sought Him, and

49 As noted by James H. Charlesworth, "Blessings (1QSb)," in The Dead Sea Scrolls, 1: Rule of the Community and Related Documents, ed. James H. Charlesworth (Tübingen: Mohr, 1994), 121. 
their renown was disputed by no man. The Stave is the Interpreter of the Law of whom Isaiah said ... [Isa. liv, $161 . .$. And the nobles of the people are those who come to dig the Well with the staves with which the Stave ordained that they should walk in all the age of wickedness-and without them they shall find nothing - until he comes who shall teach righteousness at the end of days. ( $C D$ VI 2-11)

Again we meet the רורש תורה, or "Interpreter of the Law." In this case, however, this title appears to be used not in reference to the future priestly figure mentioned above, who is also referred to as כודן הראט, but in reference to the historical Teacher of Righteousness. As Collins has recently observed, the collective evidence "suggests that such titles as Interpreter of the Law and Teacher of Righteousness could be variously used to refer to figures past or future, and that they are interchangeable." ${ }^{50}$ My purpose is met in indicating that this passage from Numbers 21 is quoted and interpreted in connection with a significant community leader.

\section{The Temple Scroll}

Even though the contents of the Temple Scroll, designated $11 Q T e m p l e^{a}$ or $11 Q 19$, deal with the ideal temple and the cultic activities associated with it, and draw heavily on Deuteronomy, Exodus, and Leviticus, it is not surprising that it also quotes or alludes to passages and phrases from Numbers. This is especially true of passages that deal with the purity of the Israelite camp/temple and with festivals and vows. The disagreement over the origins and status of the Temple Scroll at Qumran was noted above, and I realize that in many ways this text is a reworking of Torah material. This latter point raises questions of

50 John J. Collins, "Teacher and Messiah? The One Who Will Teach Righteousness at the End of Days," in The Community of the Renewed Covenant, 194; cf. 193-95. See also Collins, The Scepter and the Star, $102-4$. classification in many cases (e.g., is a given passage a "modified" quotation or does it merely show a great deal of literary dependence?). Furthermore, the inclusion of the Temple Scroll in this study tends to skew the picture of the use of passages from Numbers in principal sectarian documents since it draws upon large amounts of Torah material in a way that is quite different from most of the other principal documents. I have, therefore, as a means of illustration, limited my comments to one passage, in which it is possible to ascertain the use of Numbers in this text.

After various strictures regarding sacrifices, columns LIII 14 through LIV 5 of 11 QTemple ${ }^{a}$ contain instructions from YHWH concerning the making of and release from vows. The contents of LIII 14-21 follow Numbers 30:3-6 quite closely, although YHWH's decrees are presented in the first person, as is the style in this scroll. As expected, the orthography is full; some readings are similar to the SP and occasionally to the LXX, against the MT.

YHWH's instructions concerning vows continue into column LIV 1-5, and are based on Numbers 30:6-16, but "with certain modifications." ${ }^{, 51}$ For example, lines 4-5 concern a vow made by a widow or divorcee:

$$
\begin{aligned}
& 4 \text { וכול נדר אלמנה וגרושה כול אשר אסרה על נפשה } \\
& 5
\end{aligned}
$$

As noted by Yadin, (1) this passage comes at the end of the section on vows in $11 Q T e m p l e{ }^{a}$, after the instructions regarding a vow made by a wife, but it is located in Numbers 30:10, in the middle of the instructions on -vows, before the instructions regarding a vow made by a wife; (2) the phrase בכול אשר יצא מפיה in line 5 is not in Numbers 30:10, but derives from 30:3, in which it is used in reference to a vow made by a man; and (3) the first word in line 5, follows the LXX, against יקומו in

51 Yadin, The Temple Scroll, 2:241. Yadin's comments on this passage are found in 2:237-43. 
the MT. Even freer use of Numbers 30:13-16 appears to be exhibited in column LIV $1-3 .^{52}$

Other examples of material from Numbers can be seen in 11QTemple ${ }^{a}$ columns XVII, XV, XVII-XVIII, XLIX, and so on. ${ }^{53}$ The varied and often free use of material from Numbersthe quotations and paraphrases that agree with different witnesses of the biblical text and the reordering of passages-illustrates again both a great familiarity with the text of Numbers and the apparent lack of any concern for a received text on the part of the author. It is not exactly clear what this indicates about the community at Qumran, but suggests that they had no standard biblical text of Numbers, although some texts were similar to the so-called proto-Masoretic tradition and had no single "approved" way to incorporate biblical material into their own documents. ${ }^{54}$

\section{Varia}

A number of other passages from the Qumran sectarian literature that quote or might relate to Numbers are collected here.

52 Ibid., 2:242-43.

53 The index of biblical passages in Yadin's The Temple Scroll is convenient for locating many such passages. I have found the notations by Joseph A. Fitzmyer, The Dead Sea Scrolls: Major Publications and Tools for Study, rev. ed. (Atlanta: Scholars Press, 1990), 211-12, concerning passages of Numbers that are included in the Temple Scroll to be misleading, some that could be included are not and some that seem less than significant are included. Note that neither Vermes nor García Martinez attempted to provide citations for any biblical passages in their English translations of $11 Q T e m p l e^{a}$.

54 See, similarly, the comments of Wernberg-Møller, "The Contribution of the Hodayot," 136-37, concerning the biblical quotes and paraphrases in $1 Q H$, especially this statement: "We have in $1 \mathrm{QH}$ an apparently bewildering number of cases where the form in which a Biblical tag is quoted agrees now with this, and now with that Version, against MT. It is difficult to imagine that the author(s) composed these Hymns with a variety of recensions of the Biblical texts before them, dipping now into this, and now into that recension." Regarding $1 Q H$, he concluded that the "Biblical text" employed "exhibited these variants" (p. 137).
They generally exhibit less impact or influence than those passages already reviewed. Little if any comment is made about each of these passages, since there is not sufficient space to deal extensively with any of them.

a. Other quotations from Numbers. In addition to Numbers 21:17-18, quoted in $C D$ VI, and Numbers 24:17, quoted in $C D$ VII, $I Q M \mathrm{XI}$, and $4 Q T$ Test, there are three other quotations from Numbers included in the community's own documents (not including the Temple Scroll).

The first of these is Numbers 10:9, which appears in $1 Q M$ X 5-8 as part of the officers' instructions to their men who are participating in the great eschatological battle:

Our officers shall speak to all those prepared for battle.

They shall strengthen by the power of God the freely devoted heart, and shall make all the fearful of heart withdraw; they shall fortify all the mighty men of war. They shall recount that which $\{$ You $\}$ [said] through Moses: 'When you go to war in your land against the oppressor who oppresses you, [you] shall blow the trumpets, and you shall be remembered before your God and shall be saved from your enemies' (Num. x, 9).

While Numbers 10:1-10 contains YHWH's instructions to Moses regarding the manufacture and use, both military and nonmilitary, of two silver trumpets, the emphasis in $1 Q M \mathrm{X}$ is God's ability to preserve the righteous forces in battle. ${ }^{55}$

Second, after it is stated in $C D$ XVI 8-9 that vows to keep the Law should never be broken, "even at the price of death," and that vows that involve breaking the Law should never be fulfilled, we read concerning vows made by women:

Inasmuch as He said, It is for her husband to cancel her oath (Num. xxx,9), no husband shall cancel an oath

55 See Brooke, Exegesis at Qumran, 294, for some thoughts on the relationship between this quotation from Numbers and the quotation from Deuteronomy 20 that precedes it in $1 Q M \mathrm{X}$. 
without knowing whether it should be kept or not. Should it be such as to lead to transgression of the Covenant, he shall cancel it and shall not let it be kept. The rule for her father is likewise.(CD XVI 10-12)

Third, another passage from the same chapter of Numbers, which contains instructions from YHWH to Moses concerning vows, is quoted elsewhere in the Damascus Document:

And if they live in camps according to the rule of the Land, ... marrying . . . and begetting children, they shall walk according to the Law . . . which says, Between a man and his wife and between a father and his son (Num. xxx, 17). And all those who despise . . . shall be rewarded with the retribution of the wicked when God shall visit the Land. (CD VII 6-9)

These three passages from Numbers $(10: 9,30: 9$ and 17) quoted in $1 Q M$ and $C D$ remind us again of the covenant community's familiarity with biblical material and its ability and willingness to use it in idealized patterns of community life.

b. Possible allusions to passages in Numbers. The following remarks provide three examples of suggestions that have been made by scholars concerning passages in the community's principal documents that may either allude to or be based upon passages in Numbers but do not quote directly from it. These examples are meant to be representative, not comprehensive.

First, while the Teacher of Righteousness is never termed a "prophet" in the community's writings, it has been noted that the passage in the community's commentary on Habakkuk, $1 Q p H a b$ II 1-3, "those who were unfaithful together with the Liar, in that they [did] not [listen to the word received by] the Teacher of Righteousness from the mouth of God," is "reminiscent" of the passage in Numbers 12:8 in which YHWH declared that he spoke with Moses "mouth to mouth" (פה אל-פה; $=$ "face to face" in NRSV). ${ }^{56}$

56 Collins, The Scepter and the Star, 112.

\section{Second, according to $C D X V 5-7$ :}

And when the children [better as "sons"; בניהם] of all those who have entered הבאז] the Covenant, granted to all Israel for ever, reach the age of enrollment, they shall swear with the oath of the Covenant. And thus shall it be during all the age of wickedness for every man who repents of his corrupted way.

A relationship has been proposed between the biblical concept of תרומה, in which the priest's household shared with him in the offerings he received by virtue of his service, as prescribed in Numbers 18:11-14, 25-32, and the implication inherent in this statute in $C D \mathrm{XV}$, that while men explicitly covenanted to become a member of the covenant community, "wives and daughters were members of the sect by virtue of the status of their male relatives." 57

Third, it has been suggested that the content of Numbers 15:31 and 19:20 might be alluded to in quotations and interpretations contained in $C D$ VII and 4QFlor (4Q174) I, respectively. ${ }^{58}$ Although space does not allow evaluation of these suggestions, the very tentative nature of the suggestion regarding Numbers 15:31 and 19:20 serves to illustrate the subjective nature of attempting to posit possible allusions for specific biblical passages. ${ }^{59}$
57 Schiffman, The Eschatological Community, 17.

58 Brooke, Exegesis at Qumran, 307 (see 343 n. 144), and 136, 166, respectively.

59 Other suggested allusions to passages in Numbers can be found in Wernberg-Møller, "The Contribution of the Hodayot," 145, who cites one allusion (to Numbers 5:14) in the Hodayot; and Carmignac, "Les citations de l'Ancien Testament," 385, who cites at least ten possible allusions to Numbers in $1 Q M$. 


\section{Summary and Conclusion}

The latter portion of this study, which has surveyed the use of passages from Numbers in the Qumran sectarian documents in an effort to understand the community's regard for Numbers, can only be viewed as preliminary for two reasons. The effort and space needed to catalogue and evaluate the influence of suggested allusions to passages from Numbers in the sectarian documents would have to be far more extensive than is possible here. Furthermore, any conclusions regarding the impact of the content of Numbers on the content of the community's principal documents can only be fully evaluated and appreciated in the context of similar studies involving the other four books of the Torah, something that has not yet been undertaken.

However, this survey has revealed an interesting cross section of the kind of uses made of this biblical material in the principal documents of the community at Qumran: (1) direct quotation, often with an accompanying interpretation based on the community's world view, as in the use of passages from Numbers 10,21, 24, and 30 (not counting material in the Temple Scroll); (2) the employment of dominant phrases and words woven into the community's own works, indicating literary dependence, examples of which include the use of words and phrases from the priestly blessing of Numbers 6 in $1 Q S$ and $1 Q S b$, and possibly the use of 30:6-16 in the Temple Scroll (L IV 1-5); and (3) evidence of patterns of activity at Qumran that rely on but do not specifically cite the practices and prescriptions of the biblical text of Numbers, as was suggested, for example, regarding the ages for various types of service (based on Numbers 4 and 8 ).

My impression is that the contents of Deuteronomy and Leviticus, and probably Exodus, provide the basis for more patterns and prescriptions in the community's principal documents than is the case with Numbers. I am not sure, however, about Genesis in this regard. Discounting the Temple Scroll, relatively few passages from the Torah are actually quoted in the commu- nity's documents. The most significant passage from Numbers is the prophecy of "the star and the scepter," which is quoted in three different texts and probably alluded to in a fourth. ${ }^{60}$ Concerning the impact of Numbers on the life of the community, the correlation of certain age requirements for levitical service with age requirements for some types of service in the community and the general pattern of organization of the community are the most obvious and probably the most significant. Thus the contents of Numbers seem to have had only a moderate impact on the principal sectarian documents from Qumran. The impact may well have been greater on the lives of those who studied and accepted these documents.

Numbers was important to the Qumran community because it was part of the Torah and because of a few key passages and patterns of organization, but it was one of the less significant of those five books in the writings of the "community of the new covenant." This evaluation correlates with and reinforces the results of the quantification of textual remains discussed in the first portion of this study, in which it was noted that of all the books of the Torah, Numbers is the least represented at Qumran.

60 A survey of the quotations from the Torah (phrases to multiple verses) noted by Vermes in his English translations of $1 Q S, 1 Q S a, 1 Q S b$, $1 Q M, 4 Q T e s t$, and $4 Q F l o r$ provides the following: two from Genesis, four from Exodus, four from Leviticus, seven from Numbers, and fourteen from Deuteronomy. Vermes does not include biblical citations in 11QTemplea or $I Q H$. 


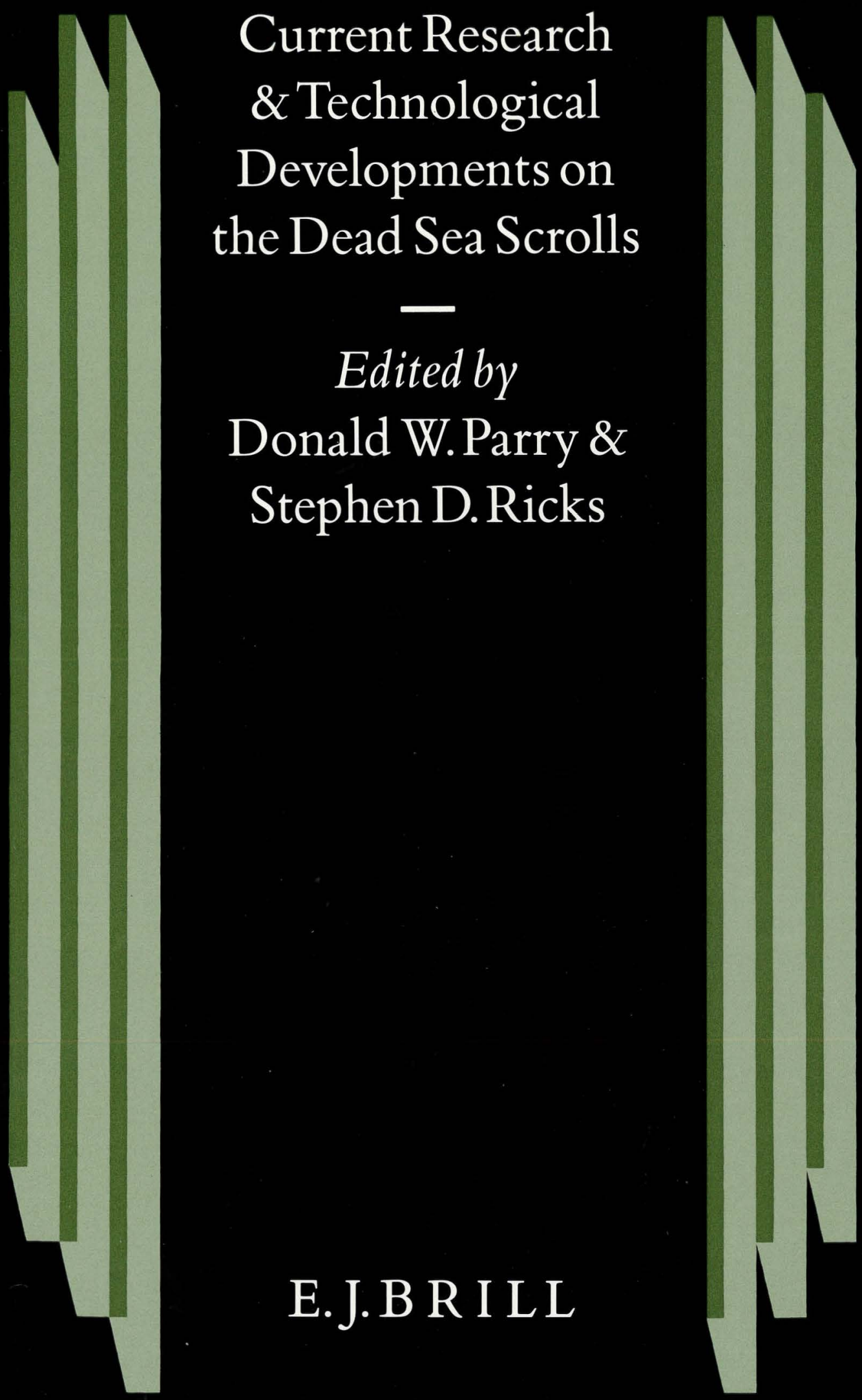




\section{CURRENT RESEARCH AND TECHNOLOGICAL DEVELOPMENTS ON THE DEAD SEA SCROLLS}

Conference on the Texts from the Judean Desert, Jerusalem, 30 April 1995

EDI'TED BY

DONALD W. PARRY

AND

STEPHEN D. RICKS

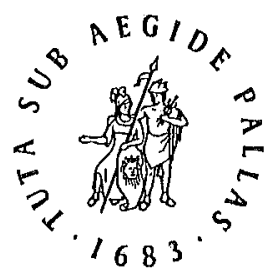

E.J. BRILL

LEIDEN $\cdot$ NEW YORK $\cdot$ KÖLN

1996 
Library of Congress Cataloging-in-Publication Data

Conference on the texts from the Judean Desert (1995 : Jerusalem)

Current research and technological developments on the dead Sea scrolls : Conference on the texts from the Judean Desert, Jerusalem, 30 April, 1995 / edited by Donald W. Parry and Stephen D. Ricks.

p. cm. -(Studies on the texts of the desert of Judah ; v.

20)

Includes index.

ISBN 9004106626 (cloth : alk. paper)

1.Dead Sea scrolls-Congresses. I.Parry, Donald W. IL Eks, Stephen David. III. Title. IV. Series.

BM487.C575 1996

296.1'55-dc20

Die Deutsche Bibliothek - CIP-Einheitsaufnahme

Current research and technological developments on the dead sea scrolls / Conference on the Texts from the Judean Desert, Jerusalem, 30 April 1995. Ed. by Donald W. Parry and Stephen D. Ricks. -Leiden;New York;Koln:Brill, 1996

(Studies on the texts of the desert of Judah; Vol. 20)

ISBN 90-04-10662-2

NE: Parry, Donald W. [Hrsg.]; Conference on the Texts from the Judean

Desert $<1995$, Yeriisiilayim $>$; GT

\section{ISSN $\quad 0169-9962$ \\ ISBN 9004106626}

(C) Copyright 1996 by E.J. Brill, Leiden, The Netherlands

All rights reserved. No part of this publication may be reproduced, translated, stored in a retrieval system, or transmitted in anyform or by any means, electronic, mechanical, photocopying, recording or otherwise, without prior written permissionfrom the publisher.

Authorization to photocopy itemsfor internal orpersonal use is granted by E.J. Brill provided that the appropriatefees are paid directly to The Copyright Clearance Center, 222 Rosewood Drive, Suite 910 Danvers MA 01923, USA.

Fees are subject to change.

PRINTED IN THE NETHERLANDS 


\section{CONTENTS}

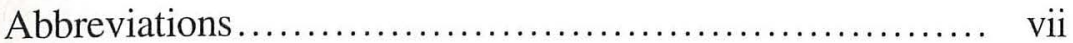

Introduction $\ldots \ldots \ldots \ldots \ldots \ldots \ldots \ldots \ldots \ldots \ldots \ldots \ldots \ldots \ldots \ldots \ldots \ldots, \quad$ ix

Frank Moore Cross, Notes on the Doctrine of the Two

Messiahs at Qumran and the Extracanonical Daniel

Apocalypse (4Q246) .............................

Florentino García Martínez, Two Messianic Figures in the Qumran Texts ............................. 14

Emanuel Tov, Scribal Markings in the Texts from the Judean Desert ..................................... 41

EugEnE UlRich, Multiple Literary Editions: Reflections toward a Theory of the History of the Biblical Text .... 78

DONALD W. PARRY, 4QSam ${ }^{a}$ and the Tetragrammaton ....... 106

TORLEIF Elgvin, Early Essene Eschatology: Judgment and Salvation according to Sapiential Work A ......... 126

DANA M. PIKE, The Book of Numbers at Qumran:

Texts and Context ............................... 166

David RolPh SEely, The Barki Nafshi Texts

(4Q434-439) .................................... 194

Scott R. Woodward, Gila Kahila, Patricia Smith, Charles

Greenblatt, Joe Zias, and Magen Broshi, Analysis of Parchment Fragments from the Judean Desert Using DNA Techniques .......................................... 215

Donald W. Parry and Steven W. Booras, The Dead

Sea Scrolls CD-ROM Database Project 